Review Article

\title{
Alterations of Antioxidant Enzymes and Biomarkers of Nitro-oxidative Stress in Tissues of Bladder Cancer
}

\author{
Md Obaidul Islam (D), Tiziana Bacchetti $(D$, and Gianna Ferretti $(1)$ \\ Department of Life and Environmental Sciences (DiSVA), Department of Clinical Science and Odontostomatology (DISCO), \\ Polytechnic University of Marche, Ancona, Italy \\ Correspondence should be addressed to Tiziana Bacchetti; t.bacchetti@univpm.it
}

Received 20 November 2018; Revised 22 February 2019; Accepted 24 March 2019; Published 5 May 2019

Academic Editor: Peeter Karihtala

Copyright (C) 2019 Md Obaidul Islam et al. This is an open access article distributed under the Creative Commons Attribution License, which permits unrestricted use, distribution, and reproduction in any medium, provided the original work is properly cited.

\begin{abstract}
Bladder cancer $(\mathrm{BC})$ is one of the most common tumors found in the urinary bladder for both male and female in western countries. In vitro and in vivo studies suggest that high levels of reactive oxygen species (ROS) and reactive nitrogen species (RNS) and oxidative stress play a crucial role in human cancer. Low concentration of ROS and RNS is indispensable for cell survival and proliferation. However, high concentration of ROS and RNS can exert a cytotoxic effect. Increased oxidative stress is a result of either increased ROS/RNS production or a decrease of antioxidant defense mechanisms. A literature search was carried out on PubMed, Medline, and Google Scholar for articles in English published up to May 2018 using the following keywords: oxidative stress, antioxidants, reactive oxygen species, lipid peroxidation, paraoxonase, urinary bladder cancer, and nitric oxide. Literature data demonstrate that $\mathrm{BC}$ is associated with oxidative stress and with an imbalance between oxidants and antioxidant enzymes. Markers of lipid peroxidation, protein and nucleic acid oxidation are significantly higher in tissues of patients with BC compared with control groups. A decrease of activity of antioxidant enzymes (superoxide dismutase, catalase, glutathione, and paraoxonase) has also been demonstrated. The imbalance between oxidants and antioxidants could have a potential role in the etiology and progression of bladder cancer.
\end{abstract}

\section{Introduction}

Bladder cancer (BC), the most common malignancy of the urinary tract, represents a crucial public health hazard due to its high aggressiveness and poor prognosis [1]. BC is the 3rd most common cancer in men and 11th most common cancer in women. Transitional bladder tumors originating from urothelial cells are classified as nonmuscle invasive (NMI) ( $\mathrm{pTa}$ or $\mathrm{pT} 1$ ) or invasive (pT2, pT3, or pT4) with the latter carrying a worse prognosis. BC has the highest recurrence rate of any other solid tumors, in which most of them exceed relapses or progresses from nonmuscle invasive to muscle invasive disease. Newly diagnosed patients, approximately $70 \%$ to $80 \%$, have nonmuscle invasive tumors and are managed by combined therapy with transurethral resection or radical cystectomy and intravesical chemotherapy $[2,3]$.
Genetic and environmental factors have been implicated in BC etiology as recently reviewed $[4,5]$. Dietary factors such as arsenic and/or environmental xenobiotics can be metabolized in the human body, and carcinogenic byproducts reach the urinary bladder via urinary excretion $[5,6]$. The molecular mechanisms by which metalloids, smoking and xenobiotics are correlated with increased oxidative stress and are potentially involved in $\mathrm{BC}$ have been previously studied [6-9]. Trivalent inorganic arsenic inhibits cell enzymes by binding to the sulfhydryl groups of dihydrolipoamide, resulting in a decreased production of cellular ATP. Moreover, trivalent arsenic inhibits the production of glutathione which protects cells against reactive oxygen species (ROS). Many other mechanistic studies of arsenic toxicity involve reactive oxygen species and reactive nitrogen species (RNS) generated during inorganic arsenic metabolism in living cells [6]. Tobacco 


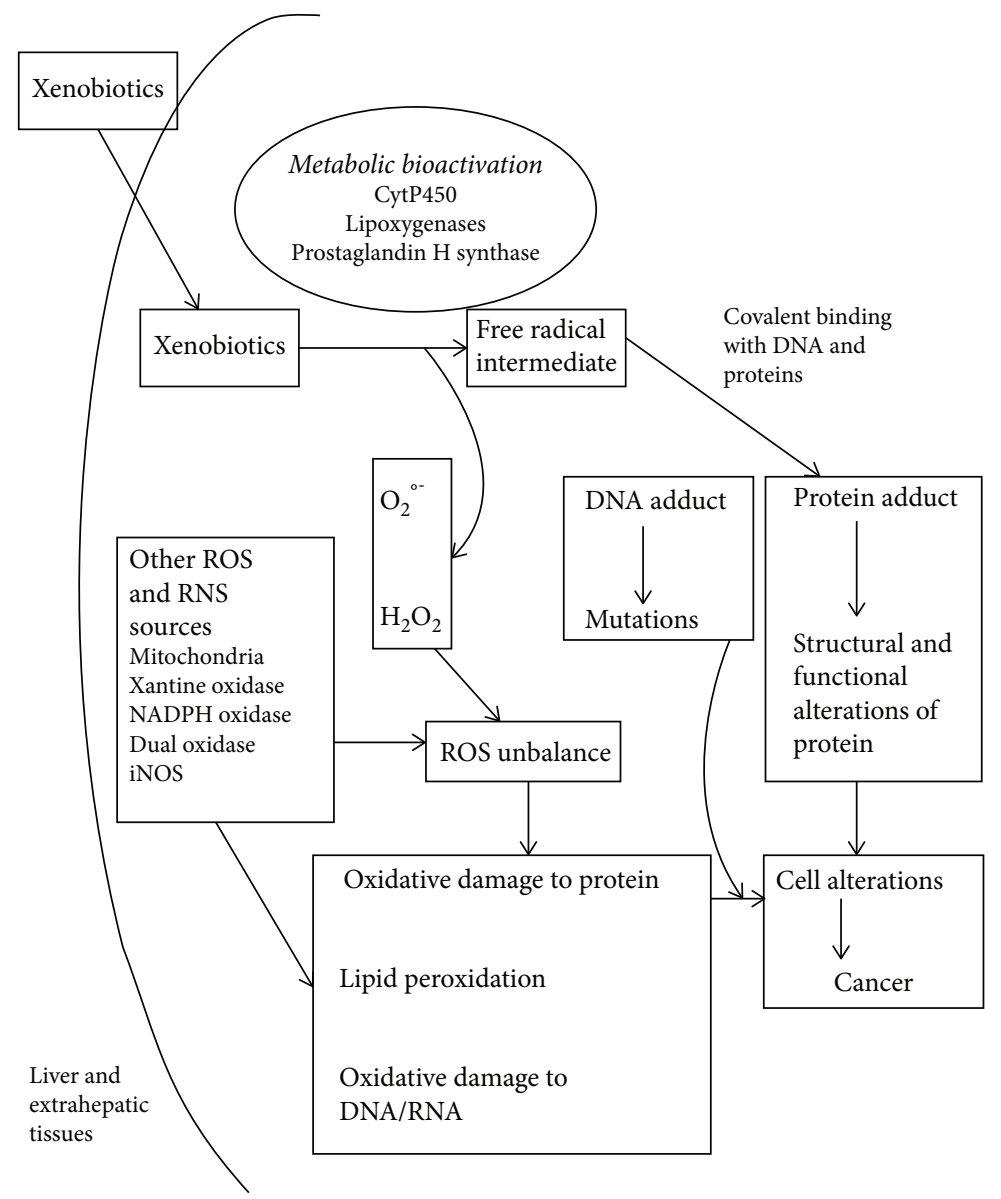

FIGURE 1: Factors potentially involved in oxidative stress in bladder cancer. Formation of xenobiotic free radical intermediates during biochemical pathways catalyzed by cytochrome P450, lipoxygenase, prostaglandin $\mathrm{H}$ synthase, and cellular effects of reactive oxygen species (ROS) and reactive nitrogen species (RNS).

smoke contains many carcinogens like polycyclic aromatic hydrocarbons (PAHs) and nitrosamines. Cigarette smoking increases the formation of ROS and RNS and together results in nitration and oxidation of plasma proteins [7, 8]. The metabolic conversion of xenobiotic chemicals in liver and extrahepatic tissues represents a key element in understanding the effects and the toxicity of industrial/environmental chemicals. During metabolic bioactivation of xenobiotics, oxidation reactions mostly catalyzed by cytochrome P-450s can lead to reactive electrophilic compounds. Cytochrome P-450s can also act as a reducing system that leads to radical intermediates which may react on oxygen to produce many ROS leading to oxidative stress. Other enzymes such as prostaglandin $\mathrm{H}$ synthase (PHS) contribute to metabolic bioactivation in extrahepatic tissues [10]. PHS exerts a role in prostaglandin generating substrate-derived free radical intermediates which can oxidize xenobiotics to biologically reactive intermediates converting them to mutagenic and carcinogenic forms (Figure 1). Eling et al. [10] has also reported relatively high levels of PHS and low levels of cytochrome P-450 in bladder epithelium. Even lipoxygenases contribute to in vivo metabolism of xenobiotics in mammals [11] (Figure 1).
This metabolism is due to two enzymatic activities, a cyclooxygenase and a peroxidase.

Intracellular antioxidant enzymes such as superoxide dismutase (SOD), catalase (CAT), and glutathione peroxidase (GTPx) exert a protective effect against oxidative damage [12]. Among detoxification and/or antioxidant systems, a key role is exerted also by the family of enzyme paraoxonases (PONs) whose physiopathological relevance in different human diseases associated with oxidative stress has been widely demonstrated [13]. Alterations of the balance of antioxidants/oxidants have a significant role in the pathogenesis of different kinds of tumors [12-16].

The literature review summarizes the state of our knowledge regarding alterations of ROS/RNS production, modifications of antioxidant enzymes, and markers of oxidative stress in bladder cancer as demonstrated in human subjects. To reach this objective, we performed a search on PubMed, Medline, and Google Scholar for articles in English published up to May 2018 using the following keywords: oxidative stress, antioxidants; catalase (CAT), superoxide dismutase (SOD), glutathione peroxidase (GTPx), reactive oxygen species (ROS), reactive nitrogen species (RNS), lipid peroxidation, paraoxonases (PONs), urinary bladder cancer, and nitric oxide. 


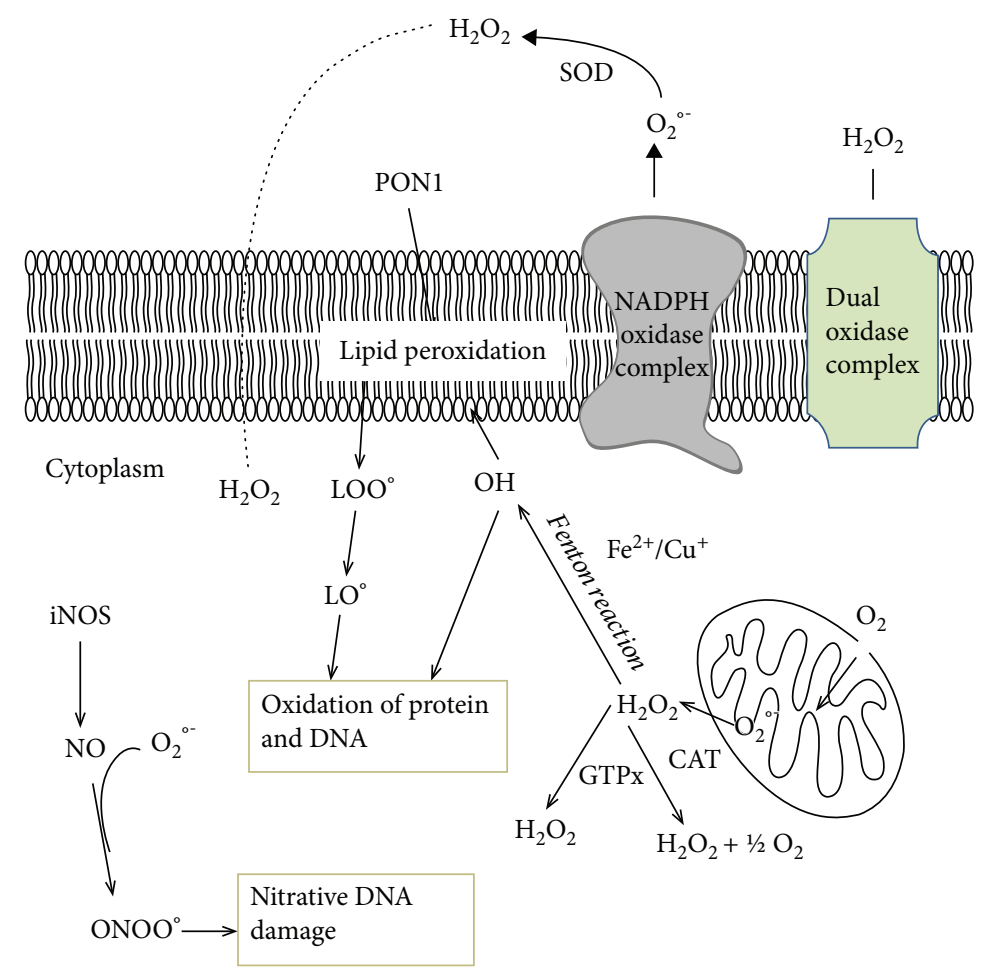

FIGURE 2: Formation of reactive oxygen species (ROS) and reactive nitrogen species (RNS) and antioxidant mechanism. Superoxide generated by NADPH oxidase complex and other different pathways may be degraded by cytosolic superoxide dismutase (SOD) and by the mitochondrial manganese-containing SOD (MnSOD) to $\mathrm{H}_{2} \mathrm{O}_{2} \cdot \mathrm{H}_{2} \mathrm{O}_{2}$ is further eliminated by catalase (CAT) and glutathione peroxidase (GTPx) enzymes. Hydrogen peroxide is produced also by the dual oxidase complex (Duox). $\mathrm{H}_{2} \mathrm{O}_{2}$ is able to cross cell membranes, and within the cells, it can react with $\mathrm{Cu}^{+} / \mathrm{Fe}^{2+}$ to form hydroxyl radicals via Fenton reaction. Nitric oxide is generated from inducible nitric oxide (iNOS). From reaction between superoxides with nitric oxide, peroxynitrite $\left(\mathrm{ONOO}^{-}\right)$is formed. Peroxynitrite $\left(\mathrm{ONOO}^{-}\right)$can damage a wide array of molecules in cells, including DNA and proteins. Reactive oxygen species (ROS) may either react directly with some amino acid residues or lead to the oxidative cleavage of the protein backbone. Other possible formation routes of protein oxidation are via the oxidation of lipids resulting in reactive molecules which react with amino acid residues and thus introduce carbonyl groups. Paraoxonase-1 (PON1) protects lipoproteins and membrane lipid from oxidative stress. Reaction of hydroxyl radicals (HO') with guanine residues of DNA contributes to DNA oxidation. If not repaired, this oxidative damage can cause mutations and/or altered gene transcription.

\section{Oxidative Stress: Role of Reactive Oxygen Species (ROS) and Reactive Nitrogen Species (RNS)}

ROS generated endogenously (mitochondria, metabolic process, inflammation, etc.) or from external sources modulate several biologic phenomena [12-15]. Under normal conditions, ROS and RNS are maintained by a balance due to enzymatic and nonenzymatic antioxidant defenses [12]. Other important sources of ROS are enzymes such as NADPH oxidases (NOXes), lipoxygenase (LOX), and myeloperoxidase (MPO) $[17,18]$. Among these enzymes, special attention has been paid to NOXes, a family of enzyme complexes (NOX1-5 and Dual oxidases DUOX1/2). These membrane-bound enzymes generate ROS which are important for cellular signaling, development, apoptosis, and protection against pathogens [19]. Superoxide ions $\left(\mathrm{O}_{2}{ }^{-}\right)$are generated by transferring electrons from $N A D P H$ inside the cell across the membrane. In addition to the superoxidegenerating NADPH oxidase domain, DUOxs also have a peroxidase domain that converts the superoxide into hydrogen peroxide. MPO converts $\mathrm{H}_{2} \mathrm{O}_{2}$ to hypochlorous acid $(\mathrm{HOCl})$, a strong oxidant that plays as a bactericidal agent in phagocytic cells. $\mathrm{H}_{2} \mathrm{O}_{2}$ is converted into a spontaneous reaction catalyzed by $\mathrm{Fe}^{2+}$ (Fenton reaction) to produce highly reactive hydroxyl radical $(\mathrm{OH})$ (Figure 2). Potential candidates for generation of oxidized lipoproteins in vivo are generated by NOX and MPO [20]. Other enzymes involved in ROS production are xanthine oxidase [21], $\alpha$-ketoglutarate dehydrogenase complex [22], d-amino acid oxidases [23], and dihydrolipoamide dehydrogenase [24]. Inducible nitric oxide synthase (iNOS), an inducible protein, produces nitric oxide (NO) [25]. RNS such as peroxynitrite $\left(\mathrm{ONOO}^{-}\right)$are generated from $\mathrm{NO}$ and superoxide ions [25].

Protein amino acid residues can be modified by RNS, and 3-nitrotyrosine is a biochemical marker of oxidative damage to proteins $[12,26]$. Protein modifications by oxidative stress result in the loss of their functions and may render proteins more prone to proteolytic degradation [26]. ROS and RNS 
TABLE 1: Modifications of expression of NADPH oxidase (NOX4), inducible nitric oxide synthase (iNOS), and nitric oxide (NO) levels in bladder cancer patients and controls.

\begin{tabular}{|c|c|c|c|}
\hline Markers & Samples & Levels & References \\
\hline NADPH oxidase (NOX4) & $\begin{array}{l}\text { Tissue } \\
\text { BC tissue }(n=82) \text { vs. normal bladder tissue }(n=82)\end{array}$ & $\begin{array}{l}2 \text {-fold increase in NO4-positive cells } \\
\qquad(/ 1000)(p<0.01)\end{array}$ & [30] \\
\hline $\begin{array}{l}\text { Inducible nitric oxide } \\
\text { synthase (iNOS) }\end{array}$ & $\begin{array}{l}\text { Tissue } \\
\text { Invasive BC }(n=14) \text { vs. noninvasive BC }(n=31) \\
\text { High grade BC }(n=33) \text { vs. low grade BC }(n=12)\end{array}$ & $\begin{array}{c}\text { iNOS pos }(\%) \\
100 \% \text { vs. } 71 \%(p=0.0399) \\
91 \% \text { vs. } 50 \%(p=0.0062)\end{array}$ & {$[31]$} \\
\hline \multirow{4}{*}{ Nitric oxide (NO) levels } & $\begin{array}{c}\text { Tissue } \\
\text { BC tissues }(n=20) \text { vs. } \text { normal bladder tissue }(n=15)\end{array}$ & $\begin{array}{c}\text { NO levels }(\mathrm{nmol} / \mathrm{g} \text { tissue }) \\
36.9 \pm 4.37 \text { vs. } 24.65 \pm 2.7(p<0.0001)\end{array}$ & {$[32]$} \\
\hline & $\begin{array}{c}\text { Serum } \\
\text { BC patients }(n=20) \text { vs. controls }(n=41)\end{array}$ & $\begin{array}{c}\text { NO levels }(\mu \mathrm{mol} / \mathrm{L}) \\
61.25 \pm 4.95 \text { vs. } 26.61 \pm 6.13(p<0.0001)\end{array}$ & {$[33]$} \\
\hline & BC patients $(n=35)$ vs. controls $(n=32)$ & $17.1 \pm 1.4$ vs. $8.1 \pm 0.8(p<0.05)$ & [32] \\
\hline & $\begin{array}{c}\text { Urine } \\
\text { BC patients }(n=20) \text { vs. controls }(n=41)\end{array}$ & $\begin{array}{l}\text { NO levels ( } \mu \mathrm{mol} / 100 \mathrm{mg} \text { urinary creatinine }) \\
4.36 \pm 0.34 \text { vs. } 1.69 \pm 0.31(p<0.0001)\end{array}$ & {$[32]$} \\
\hline
\end{tabular}

can contribute also to oxidative damage to lipids and nucleic acids [27-29]. Lipid hydroperoxides, acrolein, malondialdehyde (MDA), and 4-hydroxy-2-nonenal (HNE) are useful biomarkers of oxidative stress to lipids [28, 29]. Therefore, in conditions characterized by an imbalance between ROS/RNS levels and antioxidants, oxidative cell injury may occur and trigger oxidation of lipids, proteins, and DNA. Many studies have demonstrated that cancer cells exhibit elevated ROS production [16]. Different molecular mechanisms are involved such as alterations of mitochondria and peroxisome, increased activity of metabolic transduction pathways, and transcriptional cellular receptor signaling [14-16]. Increased levels of ROS can sustain cellular proliferation and/or prolonged differentiation $[14,15]$. In fact, cell redox potential affects transcription factors that regulate the expression of genes responsible for proliferation, apoptosis, angiogenesis, and production of cytokines [15].

\section{ROS Generation, Oxidants, and Antioxidants in Bladder Cancer}

3.1. NADPH Oxidase (NOX). ROS production via NADPH oxidase (NOX) contributes to various types of cancer progression. As aforementioned, the NOX family comprises different isoforms: (NOX1-5). The pathobiological role of NADPH oxidase-mediated generation of ROS has also been studied in urothelial carcinoma (UC) of the urinary bladder [30]. Using immunohistochemistry, Shimada et al. [30] demonstrated that NOX4 was seldom expressed in normal urothelium. An overexpression was demonstrated in highgrade, superficially, and deeply invasive carcinomas but not in low-grade and noninvasive phenotypes. However, NOX4 expression level was not correlated to pathological parameters such as grade, stage, and tumor [30]. Furthermore, using human urothelial carcinoma cell lines in culture, it has been demonstrated that NOX4 silencing reduced ROS generation and suppressed cancer cell growth via p16-dependent cell cycle arrest at the G1 phase. These experimental evidences suggest that NOX4-mediated ROS generation can play a role in the molecular mechanisms involved in the early steps in urothelial carcinogenesis and cancer cell survival. In addition, NOX4-mediated enhancement of ROS generation resulted in more aggressive phenotype bladder cancer cells. These experimental evidences suggest that ROS generation via NOXes could represent a useful index in the cytological diagnosis of urothelial carcinoma (Table 1).

3.2. iNOS and Nitro-oxidative Stress. As aforementioned, iNOS is an inducible enzyme which produces NO [25]. Particularly, $\mathrm{NO}$ is an endogenous molecule that plays several physiological and pathophysiological roles in cancer biology and transmission of cellular signals [31]. The effect appears to be concentration-dependent. Low concentrations of NO (pico- to nanomolar range) lead to tumor promotion. On the contrary, proapoptotic functions leading to tumor suppression are triggered by higher NO concentrations (micromolar range) [31, 32]. Under oxidative stress and during inflammation, the cellular biosynthesis of iNOS is increased [33]. iNOS expression has been detected in bladder cancers as a higher expression, and activity has been observed in bladder tumoral tissue with respect to nontumoral tissues. The higher expression of iNOS is associated with an increased NO production [31]. An excessive production of iNOS also correlates with transition to more advanced stages of bladder cancer as demonstrated by Sandes et al. [31] (Table 1). The higher levels of NO observed in bladder cancer tissue and urine of $\mathrm{BC}$ patients with respect to healthy subjects are likely related to the higher activity of iNOS in tumoral tissue. Higher levels of NO concentrations have been also confirmed in serum $[32,33]$. A potential role of NO in bladder cancer is supported by the comparison of serum concentrations of $\mathrm{NO}$ in $\mathrm{BC}$ patients before and after surgery. A decrease of NO levels has been observed after surgery with respect to the preoperative state. After surgery, NO levels did not differ statistically from concentrations in the control group [32]. Studies in cells in culture demonstrate that NO exerts a dichotomous effect in bladder cancer. Low concentrations are responsible for the modulation of the growth of bladder tumor cells [34]. High concentrations of NO in bladder cancer cells exposed to cytokine tumor necrosis factor and IL-1B trigger apoptosis [34]. 
TABLE 2: Modifications of antioxidant enzymes in bladder cancer patients and controls.

\begin{tabular}{|c|c|c|c|}
\hline $\begin{array}{l}\text { Biochemical } \\
\text { markers }\end{array}$ & Samples & Enzyme activities and levels & References \\
\hline \multirow{6}{*}{$\begin{array}{l}\text { Superoxide } \\
\text { dismutase } \\
\text { (SOD) }\end{array}$} & $\begin{array}{c}\text { Tissue } \\
\text { BC tissue }(n=75) \text { vs. normal bladder tissue }(n=30)\end{array}$ & $\begin{array}{c}\text { SOD positive }(\%) \\
49.3 \% \text { vs. } 80 \%(p=0.007)\end{array}$ & {$[35]$} \\
\hline & BC tissue $(n=25)$ vs. normal bladder tissue $(n=15)$ & $\begin{array}{c}\text { SOD activity (IU/mg) } \\
0.0715 \pm 0.0056 \text { vs. } 0.1407 \pm 0.0134(p<0.0001)\end{array}$ & {$[36]$} \\
\hline & BC tissues $(n=25)$ vs. normal bladder tissue $(n=26)$ & $\begin{array}{l}\text { SOD activity (U/mg) } \\
40 \text { vs. } 80\end{array}$ & {$[37]$} \\
\hline & BC tissue $(n=36)$ vs. normal bladder tissue $(n=9)$ & $\begin{array}{c}\text { SOD activity }(\mathrm{U} / \mathrm{mg} \text { prot }) \\
16.5 \pm 4.5 \text { vs. } 1.49 \pm 0.61(p<0.05)\end{array}$ & {$[38]$} \\
\hline & $\begin{array}{c}\text { Serum } \\
\text { BC patients }(n=50) \text { vs. controls }(n=50)\end{array}$ & $\begin{array}{c}\text { SOD activity }(\mathrm{U} / \mathrm{mL}) \\
149.14 \pm 29.65 \text { vs. } 201 \pm 31.4(p<0.001)\end{array}$ & [39] \\
\hline & BC patients $(n=50)$ vs. controls $(n=40)$ & $28.49 \pm 14.03$ vs. $194.0 \pm 28.48(p<0.001)$ & [40] \\
\hline \multirow{4}{*}{ Catalase (CAT) } & $\begin{array}{c}\text { Tissue } \\
\text { BC tissue }(n=75) \text { vs. normal bladder tissue }(n=30)\end{array}$ & $\begin{array}{c}\text { CAT positive (\%) } \\
44 \% \text { vs. } 73.3 \%(p=0.012)\end{array}$ & {$[35]$} \\
\hline & BC tissue $(n=25)$ vs. normal bladder tissue $(n=15)$ & $\begin{array}{c}\text { CAT activity (IU/mg) } \\
6.220 \pm 0.991 \text { vs. } 11.651 \pm 3.684(p<0.0001)\end{array}$ & {$[36]$} \\
\hline & BC tissue $(n=36)$ vs. normal bladder tissue $(n=9)$ & $\begin{array}{c}\text { CAT activity }(\mathrm{IU} / \mathrm{mg}) \\
33.7 \pm 11.5 \text { vs. } 60.2 \pm 26.9(p<0.01)\end{array}$ & {$[38]$} \\
\hline & $\begin{aligned} & \text { Serum } \\
& \text { BC patients }(n=50) \text { vs. controls }(n=50)\end{aligned}$ & $\begin{array}{c}\text { CAT activity }(\mathrm{u} / \mathrm{L}) \\
10.4 \pm 2.4 \text { vs. } 20 \pm 4.3(p<0.001)\end{array}$ & [39] \\
\hline \multirow{6}{*}{$\begin{array}{l}\text { Glutathione } \\
\text { peroxide } \\
\text { (GTPx) }\end{array}$} & $\begin{array}{c}\text { Tissue } \\
\text { BC tissue }(n=75) \text { vs. normal bladder tissue }(n=30)\end{array}$ & $\begin{array}{c}\text { GTPx positive (\%) } \\
45.3 \% \text { vs. } 63.3 \%(p=0.146)\end{array}$ & {$[35]$} \\
\hline & BC tissue $(n=25)$ vs. normal bladder tissue $(n=15)$ & $\begin{array}{c}\text { GTPx activity (IU/mg) } \\
0.232 \pm 0.009 \text { vs. } 0.523 \pm 0.034(p<0.0001)\end{array}$ & {$[36]$} \\
\hline & BC tissue $(n=25)$ vs. normal bladder tissue $(n=26)$ & $\begin{array}{l}\text { GTPx activity }(\mathrm{U} / \mathrm{g}) \\
35 \text { vs. } 85\end{array}$ & [37] \\
\hline & $\begin{array}{c}\text { Serum } \\
\text { BC patients }(n=50) \text { vs. controls }(n=50)\end{array}$ & $\begin{array}{c}\text { GTPx activity (U/L) } \\
131.00 \pm 14.46 \text { vs. } 170 \pm 28(p<0.001)\end{array}$ & [39] \\
\hline & BC patients $(n=50)$ vs. controls $(n=40)$ & $1693.09 \pm 544.01$ vs. $6906 \pm 847(p<0.001)$ & {$[40]$} \\
\hline & $\begin{array}{l}\text { Erythrocyte } \\
\text { Grade III BC patients }(n=22) \text { vs. controls }(n=23)\end{array}$ & $\begin{array}{l}\text { GTPx activity }(\mathrm{U} / \mathrm{g} \mathrm{Hb}) \\
4 \text { vs. } 5(p<0.001)\end{array}$ & {$[43]$} \\
\hline \multirow{2}{*}{$\begin{array}{l}\text { Glutathione } \\
\text { (GSH) }\end{array}$} & $\begin{array}{c}\text { Tissue } \\
\text { BC tissue }(n=7) \text { vs. normal bladder tissue }(n=14)\end{array}$ & $\begin{array}{c}\text { GSH levels }(\mu \mathrm{M} / \mathrm{mg}) \\
1.345 \pm 1.252 \text { vs. } 7.887 \pm 6.176(p<0.001)\end{array}$ & {$[42]$} \\
\hline & BC tissues $(n=25)$ vs. normal bladder tissue $(n=26)$ & $\begin{array}{l}\text { GSH levels }(\mathrm{mg} / \mathrm{mL}) \\
35 \text { vs. } 75\end{array}$ & {$[37]$} \\
\hline \multirow{3}{*}{$\begin{array}{l}\text { Paraoxonase-1 } \\
\text { (PON1) }\end{array}$} & $\begin{array}{c}\text { Serum } \\
\text { BC patients }(n=56) \text { vs. controls }(n=57)\end{array}$ & $\begin{array}{c}\text { PON1 paraoxonase activity (U/L) } \\
103.35 \pm 41.44 \text { vs. } 137.63 \pm 53.37(p=0.0001) \\
\text { PON1 arylesterase activity }(\mathrm{U} / \mathrm{L}) \\
131.83 \pm 39.94 \text { vs. } 168.82 \pm 37.34(p=0.0001)\end{array}$ & [47] \\
\hline & BC patients $(n=29)$ vs. controls $(n=61)$ & $\begin{array}{c}\text { PON1 paraoxonase activity (U/L) } \\
239.1(116.6-457.4) \text { vs. } 253.1(149.5-434.7)\end{array}$ & \multirow{2}{*}{ [48] } \\
\hline & BC patients $(n=29)$ vs. controls $(n=61)$ & $\begin{array}{c}\text { PON1 concentration }(\mathrm{mg} / \mathrm{L}) \\
70.6(18.2-185.2) \text { vs. } 101.6(52.9-325.1)\end{array}$ & \\
\hline \multirow{2}{*}{$\begin{array}{l}\text { Paraoxonase-2 } \\
\text { (PON2) }\end{array}$} & $\begin{array}{c}\text { Tissue } \\
\text { BC tissues }(n=17) \text { vs. normal bladder tissue }(n=17)\end{array}$ & $\begin{array}{c}\text { PON2 expression levels: } \\
\text { 2.01-fold higher in BC tissue vs. normal tissue }(p<0.05)\end{array}$ & {$[49]$} \\
\hline & BC tissues vs. normal bladder tissue & $\begin{array}{l}\text { PON2 expression levels: } \\
\text { 4.01-fold higher BC tissue vs. normal tissue }(p<0.05)\end{array}$ & {$[44]$} \\
\hline
\end{tabular}

\section{Cellular and Extracellular Antioxidant Enzymes}

The activity and expression of different antioxidant enzymes such as superoxide dismutase (SOD), catalase (CAT), glutathione peroxidase (GTPx), and paraoxonases (PONs) have been studied in BC patients. Literature data are summarized in Table 2.

4.1. Superoxide Dismutase (SOD). Copper-zinc superoxide dismutase $(\mathrm{Cu}, \mathrm{Zn}-\mathrm{SOD})$ plays a protective role in various types of tissue protecting them from oxidative damage. 
Lower levels of SOD activity in the tumor tissue of bladder cancer patients in comparison to benign tumors have been observed [35-38]. SOD expression is significantly lower in invasive transitional cell carcinomas than in superficial transitional cell carcinomas [35]. Modifications of SOD have been demonstrated also in serum isolated from BC patients $[39,40]$ (Table 2).

4.2. Catalase (CAT). CAT protects cells against the excessive formation of reactive oxygen species and prevents the accumulation of $\mathrm{H}_{2} \mathrm{O}_{2}$. A decreased CAT expression [35] and activity $[36,38]$ in cancerous bladder tissue comparison with control bladder tissues have been reported. Modifications of CAT activity were observed also in serum of BC patients [39].

4.3. Glutathione and Peroxidase (GTPx). GSH exerts a key antioxidant intracellular role [41] and is also involved in many metabolic processes. GSH and the enzymes involved in its metabolism such as glutathione S-transferase, glutathione peroxidase, and glutathione reductase play an important role in several diseases, including cancer [41]. Lower values of GTPx activity were found in erythrocytes and in bladder cancer tissues, both in comparison with the bladder tissues of patients without tumors, and in comparison with normal tissues of the bladders with tumors [37, 42, 43]. Therefore, a decrease of GSH could contribute to a shift in an intracellular environment to a prooxidant state leading to multiple changes.

4.4. Paraoxonase 1 (PON1). Among antioxidant and antiinflammatory enzymes, paraoxonase includes three different proteins such PON1, PON2, and PON3. All enzymes behave as an antioxidant $[13,44-46]$. Mainly, PON1 and PON3 are localized in the plasma. PON2 is localized in the plasma membrane, endoplasmic reticulum, nuclear envelop, and inner mitochondrial membrane. These enzymes protect biological membranes and lipoproteins against potentially harmful ROS which contribute to lipid peroxidation (Figure 2). Many studies have investigated the relationship between PON enzymes and various diseases that involve oxidative stress $[13,44-46]$. PON1 activities could be evaluated using different substrates including paraoxon (PON1 paraoxonase activity) and phenyl-acetate (PON1 arylesterase activity). PON1 paraoxonase and arylesterase activities were significantly decreased in the serum of BC subjects with respect to controls [47].

More recently, also, a decrease of serum paraoxonase-1 concentration has been demonstrated in patients with urinary bladder cancer. The lower serum PON1 concentrations were associated with higher levels of chemokine (C-C motif) ligand $2 \mathrm{C}$-reactive protein than the control individuals [48]. Moreover, a relationship between PON1 and clinical data was reported with lower PON1 concentration in patients with tumor recurrence with respect to patients without tumor recurrence [48]. Several studies in chronic diseases have demonstrated that a low PON1 activity in serum exposes subjects to a higher oxidative stress [49]. The relationship between PON1 gene polymorphism and $\mathrm{BC}$ has demonstrated that RR genotype was more common in bladder tumors [50].

4.5. Paraoxonase 2 (PON2). PON2 is a member of multiple gene family of paraoxonase that represents an intracellular enzyme localized in the plasma membrane, endoplasmic reticulum, nuclear envelope, and inner mitochondrial membrane. A protective effect against lipid peroxidation and intracellular ROS formation is exerted by PON2 [44]. Due to its localization in the ER and mitochondria, PON2 could act as an antiapoptotic effect that can be of physiopathological relevance in tumor cells [43-46]. In addition to alterations of activity and concentration of PON1, modifications of PON2 have been demonstrated in BC $[44,51]$. The comparison of expression levels of PON2 in paired tumor and normal bladder tissue samples from patients affected with $\mathrm{BC}$, most of which underwent radical cystectomy for the treatment of advanced disease (pT3-4), has shown that PON2 expression levels were significantly higher (2.01-fold) in $\mathrm{BC}$ compared with those detected in normal tissue [51]. Furthermore, PON2 expression in urinary exfoliated cells obtained in BC patients was significantly higher compared to that in patients affected with tumors invading subepithelial connective tissue or extending outside the bladder (pT1-3). PON2 overexpression on bladder tumor cells (T24) was associated with higher proliferation and lower susceptibility to oxidative stress by tert-butyl hydroperoxide. Upregulated levels of PON2 have been detected in different types of cancer cells including $\mathrm{BC}$, and a possible involvement of the role of $P O N 2$ higher expression in apoptotic escape of tumor cells has been suggested [51].

\section{Markers of Lipid, Protein, and Nucleic Acid Oxidative Stress in Bladder Cancer}

Previous studies have demonstrated higher levels of biochemical markers of oxidative stress of lipid, proteins, and nucleic acids in BC patients (Table 3).

5.1. Lipid Peroxidation. A significant increase of malondialdehyde (MDA) has been observed by different authors in the serum and plasma of BC patients [33, 40,43]. The higher levels of MDA, the major aldehyde product of lipid peroxidation of membrane polyunsaturated fatty acids by free radicals, demonstrates that oxidative stress realizes in biological membranes and/or plasma lipoproteins in bladder cancer patients. Badjatia et al. confirmed an increase of lipid peroxidation in more advanced bladder cancer [40].

Other markers of lipid peroxidation have been studied in bladder cancer tissue. Higher levels of 4-HNE were observed in the bladder cancer tissues compared with the non tumorous tissue. 4-HNE was mainly detectable in the cytoplasm of cancer cells [52]. Even acrolein is a byproduct of lipid peroxidation [53]. Higher levels of $\gamma$-OH-acrolein-dG DNA adducts have been reported in bladder tumor tissues compared to normal human urothelial mucosa. It has been suggested that tumor cells could be more susceptible to adduct formation and/or tumor cells have a lower repair capacity. Whatever are the causes of the higher levels of 
TABLE 3: Markers of oxidative stress in bladder cancer patients and control subjects.

\begin{tabular}{|c|c|c|c|}
\hline Biochemical markers & Samples & Levels & References \\
\hline \multirow{4}{*}{ Malondialdehyde (MDA) } & Serum & $\operatorname{MDA}(\mathrm{nmol} / \mathrm{mL})$ & \multirow[b]{2}{*}[40]{} \\
\hline & BC patients $(n=50)$ vs. controls $(n=40)$ & $13.91 \pm 8.59$ vs. $2.12 \pm 0.78(p<0.0001)$ & \\
\hline & BC patients $(n=35)$ vs. controls $(n=32)$ & $16.8 \pm 1.6$ vs. $9.1 \pm 0.4(p<0.05)$ & [33] \\
\hline & Grade III BC patients $(n=22)$ vs. controls $(n=23)$ & $\begin{array}{l}\text { MDA }(\mathrm{nmol} / \mathrm{mL}) \\
4 \text { vs. } 1(p<0.001)\end{array}$ & [43] \\
\hline Acrolein-dG DNA adducts & $\begin{array}{c}\text { Tissue } \\
\text { BC tissue }(n=10) \text { vs. normal bladder tissue }(n=19)\end{array}$ & $\begin{array}{c}\text { DNA adduct/dG } \times 10^{7} \\
(63 \pm 25) \times 10^{-7} / \mathrm{dG} \text { vs. }(25 \pm 10) \times 10^{-7} / \mathrm{dG}\end{array}$ & [54] \\
\hline \multirow{3}{*}{$\begin{array}{l}\text { Total antioxidant status } \\
\text { (TAS) }\end{array}$} & $\begin{array}{c}\text { Serum } \\
\text { BC patients }(n=56) \text { vs. controls }(n=57)\end{array}$ & $\begin{array}{c}\text { TAS (mmol Trolox equiv./L) } \\
0.91 \pm 0.17 \text { vs. } 0.99 \pm 0.12(p<0.010)\end{array}$ & [47] \\
\hline & BC patients $(n=50)$ vs. controls $(n=40)$ & $\begin{array}{c}\text { TAS }(\mathrm{mM}) \\
0.99 \pm 0.06 \text { vs. } 1.45 \pm 0.22(p<0.001)\end{array}$ & {$[40]$} \\
\hline & BC patients $(n=35)$ vs. controls $(n=32)$ & $\begin{array}{l}\text { TAS (mmol Trolox equiv./L) } \\
1.1 \pm 0.1 \text { vs. } 2.5 \pm 0.2(p<0.05)\end{array}$ & {$[33]$} \\
\hline Total oxidant status & $\begin{array}{c}\text { Serum } \\
\text { BC patients }(n=56) \text { vs. controls }(n=57)\end{array}$ & $\begin{array}{c}\text { TOS }\left(\mathrm{mmol} \mathrm{H}_{2} \mathrm{O}_{2} \text { equiv./L) }\right. \\
24.68 \pm 6.84 \text { vs. } 17.55 \pm 7.79(p=0.001)\end{array}$ & [47] \\
\hline $\begin{array}{l}\text { Protein carbonyl groups } \\
(\mathrm{PCO})\end{array}$ & $\begin{array}{c}\text { Plasma } \\
\text { BC patients }(n=43) \text { vs. controls }(n=28)\end{array}$ & $\begin{array}{c}\text { PCO }(\mathrm{nmol} / \mathrm{mg} \text { protein }) \\
0.682 \pm 0.094 \text { vs. } 0.606 \pm 0.077(p<0.001)\end{array}$ & [55] \\
\hline Protein thiol & BC patients $(n=43)$ vs. controls $(n=28)$ & $\begin{array}{l}\text { Protein thiol }(\mu \mathrm{mol} / \mathrm{L}) 311.427 \pm 89.507 \text { vs. } \\
366.181 \pm 57.717(p<0.01)\end{array}$ & \\
\hline 8-OHdG & $\begin{array}{c}\text { Tissue } \\
\text { BC tissue }(n=31) \text { vs. normal bladder tissue }(n=31)\end{array}$ & $\begin{array}{c}\text { 8-OhdG } n g / m L / m g ~ D N A \\
72.7 \pm 16.6 \text { vs. } 42.2 \pm 15.3(p=0.072)\end{array}$ & [58] \\
\hline
\end{tabular}

acrolein in the bladder tumor cells than in normal human urothelial mucosa, the increased levels may favour the formation of higher levels of acrolein-dG DNA adducts [54]. Acrolein adduction of DNA, if not repaired efficiently, has the potential cause to critical gene mutations, suggesting that acrolein may be mutagenic and may contribute to the process of carcinogenesis.

A deregulation of oxidative/antioxidant balance in bladder cancer is also suggested by the significant modifications of total antioxidant status (TAS) and total oxidant status (TOS) in the serum of BC subjects. The TAS indicates the overall antioxidative status of the serum, while the TOS denotes the oxidative status of the serum [33, 40, 47]. The significant decrease of the oxidative stress index (OSI) calculated as the ratio between TOS and TAS values confirms that $\mathrm{BC}$ is associated with oxidative stress [47].

5.2. Protein Oxidation. ROS and RNS favour oxidative stress of cell proteins. Levels of protein carbonyl groups are remarkably higher in bladder cancer patients than in healthy controls [55]. Patients with bladder cancer have also significantly lower levels of total thiol groups and protein-bound thiol groups as compared to healthy controls [55].

5.3. Nucleic Acids. RNS like ROS can directly damage the molecule DNA, while inhibiting its repair. The formation of 8-hydroxy-2' -deoxyguanosine (8-OHdG), oxidative damage to guanine $(\mathrm{G})$, is the most common form of oxidative DNA damage $[29,56]$. This base modification increases by $35-50 \%$ in individuals using tobacco smoke, a well-known carcinogenic source of ROS [57]. Higher levels of $8-\mathrm{OHdG}$ were found in bladder cancer tissues than in the surrounding cancer-free tissues at various stages of the disease [58]. All these results confirm that oxidative stress realizes in BC. Oxidative stress reflects also in mitochondrial DNA (mtDNA) damage mutations and mtDNA instability as demonstrated in human cancers [59]. The increased levels of mtDNA found in both the urine and plasma of patients with bladder cancer may suggest endogenous tumor necrosis and release of mtDNA into both the urine and plasma [60].

\section{Conclusions}

The production of ROS and RNS through either endogenous or exogenous insults plays a major role in the aging process and age-related disease. Numerous epidemiological, experimental, and clinical studies have demonstrated that markers of oxidative stress are associated with the development and progression of cancer. The higher levels of markers of lipid, protein, and DNA oxidation demonstrated in BC tissues confirm a potential role of oxidative stress in the molecular mechanism of the disease. Literature data suggest an overproduction of $\mathrm{NO}$ and/or a deficiency in the antioxidant systems (SOD, CAT, and GTPx) in the bladder tissue, serum, and plasma of $\mathrm{BC}$ patients. Among antioxidant enzymes, a decrease of serum PON1 has also been reported. Several 
molecular mechanisms could be implicated in the cancerrelated decrease in the activities of antioxidant enzymes such as a downregulation of synthesis by proinflammatory cytokines such as TNF $\alpha$ and IL-1. Overall, the results of our review confirm that bladder cancer is associated with a shift in the antioxidant/pro-oxidant balance. The cause of the imbalance is unknown. Dietary and environmental factors, prolonged exposure to carcinogens, and/or accumulation of genetic and cellular damage could be the most powerful candidates.

\section{Abbreviations}

$\begin{array}{ll}\text { ARE: } & \text { Arylesterase } \\ \text { CAT: } & \text { Catalase } \\ \text { DUOX: } & \text { Dual oxidase } \\ \text { ER: } & \text { Endoplasmic reticulum } \\ \text { GSH: } & \text { Glutathione } \\ \text { GTPx: } & \text { Glutathione peroxidase } \\ \text { 4-HNE: } & \text { 4-Hydroxynonenal } \\ \text { iNOS: } & \text { Inducible NO synthase } \\ \text { IL-1: } & \text { Interleukin-1 } \\ \text { LOX: } & \text { Lipoxygenase } \\ \text { MDA: } & \text { Malondialdehyde } \\ \text { MPO: } & \text { Myeloperoxidase } \\ \text { NOXes: } & \text { NADPH oxidases } \\ \text { OSI: } & \text { Oxidative stress index } \\ \text { PON: } & \text { Paraoxonase } \\ \text { PON1: } & \text { Paraoxonase-1 } \\ \text { PON2: } & \text { Paraoxonase-2 } \\ \text { PON3: } & \text { Paraoxonase-3 } \\ \text { PHS: } & \text { Prostaglandin H synthase } \\ \text { RNS: } & \text { Reactive nitrogen species } \\ \text { ROS: } & \text { Reactive oxygen species } \\ \text { SOD: } & \text { Superoxide dismutase } \\ \text { TAS: } & \text { Total antioxidant system } \\ \text { TOS: } & \text { Total oxidant system } \\ \text { TNF }: & \text { Tumor necrosis factor-alpha. }\end{array}$

\section{Conflicts of Interest}

The authors declare no conflict of interest.

\section{Authors' Contributions}

Md Obaidul Islam, Tiziana Bacchetti, and Gianna Ferretti contributed equally to the preparation of the manuscript.

\section{References}

[1] D. M. Parkin, "The global burden of urinary bladder cancer," Scandinavian Journal of Urology and Nephrology, vol. 42, Supplement 218, pp. 12-20, 2008.

[2] S. F. Shariat, J. A. Karam, Y. Lotan, and P. I. Karakiewizc, "Critical evaluation of urinary markers for bladder cancer detection and monitoring," Reviews in Urology, vol. 10, no. 2, pp. 120-135, 2008.

[3] J. Bellmunt, A. Orsola, J. J. Leow et al., "Bladder cancer: ESMO practice guidelines for diagnosis, treatment and follow-up," Annals of Oncology, vol. 25, Supplement_3, pp. iii40-iii48, 2014.

[4] J. Ferris, O. Berbel, J. Alonso-Lopez, J. Garcia, and J. A. Ortega, "Environmental non-occupational risk factors associated with bladder cancer," Actas Urológicas Españolas (English Edition), vol. 37, no. 9, pp. 579-586, 2013.

[5] D. Volanis, T. Kadiyska, A. Galanis, D. Delakas, S. Logotheti, and V. Zoumpourlis, "Environmental factors and genetic susceptibility promote urinary bladder cancer," Toxicology Letters, vol. 193, no. 2, pp. 131-137, 2010.

[6] K. Jomova, Z. Jenisova, M. Feszterova et al., "Arsenic: toxicity, oxidative stress and human disease," Journal of Applied Toxicology, vol. 31, no. 2, pp. 95-107, 2011.

[7] B. Isik, A. Ceylan, and R. Isik, "Oxidative stress in smokers and non-smokers," Inhalation Toxicology, vol. 19, no. 9, pp. 767769, 2007.

[8] S. Petruzzelli, R. Puntoni, P. Mimotti et al., "Plasma 3-nitrotyrosine in cigarette smokers," American Journal of Respiratory and Critical Care Medicine, vol. 156, no. 6, pp. 1902-1907, 1997.

[9] F. Henkler, J. Brinkmann, and A. Luch, "The role of oxidative stress in carcinogenesis induced by metals and xenobiotics," Cancers, vol. 2, no. 2, pp. 376-396, 2010.

[10] T. E. Eling, D. C. Thompson, G. L. Foureman, J. F. Curtis, and M. F. Hughes, "Prostaglandin H synthase and xenobiotic oxidation," Annual Review of Pharmacology and Toxicology, vol. 30, no. 1, pp. 1-45, 1990.

[11] A. P. Kulkarni, "Lipoxygenase - a versatile biocatalyst for biotransformation of endobiotics and xenobiotics," Cellular and Molecular Life Sciences, vol. 58, no. 12, pp. 18051825, 2001.

[12] L. A. Pham-Huy, H. He, and C. Pham-Huy, "Free radicals, antioxidants in disease and health," International journal of biomedical science: IJBS, vol. 4, no. 2, pp. 89-96, 2008.

[13] A. Devarajan, D. Shih, and S. T. Reddy, "Inflammation, infection, cancer and all that the role of paraoxonases," in Oxidative Stress and Inflammation in Non-communicable Diseases Molecular Mechanisms and Perspectives in Therapeutics, J. Camps, Ed., vol. 824 of Advances in Experimental Medicine and Biology, pp. 33-41, Springer, Cham, 2014.

[14] J. N. Moloney and T. G. Cotter, "ROS signalling in the biology of cancer," Seminars in Cell \& Developmental Biology, vol. 80, pp. 50-64, 2018.

[15] M. Benhar, D. Engelberg, and A. Levitzki, "ROS, stressactivated kinases and stress signaling in cancer," $E M B O$ Reports, vol. 3, no. 5, pp. 420-425, 2002.

[16] M. Valko, C. J. Rhodes, J. Moncol, M. Izakovic, and M. Mazur, "Free radicals, metals and antioxidants in oxidative stressinduced cancer," Chemico-Biological Interactions, vol. 160, no. 1, pp. 1-40, 2006.

[17] Y. Miyata, T. Matsuo, Y. Sagara, K. Ohba, K. Ohyama, and H. Sakai, "A mini-review of reactive oxygen species in urological cancer: correlation with NADPH oxidases, angiogenesis, and apoptosis," International Journal of Molecular Sciences, vol. 18, no. 10, article 2214, 2017.

[18] K. J. Cho, J. M. Seo, and J. H. Kim, "Bioactive lipoxygenase metabolites stimulation of NADPH oxidases and reactive oxygen species," Molecules and Cells, vol. 32, no. 1, pp. 1-5, 2011.

[19] Á. Donkó, Z. Péterfi, A. Sum, T. Leto, and M. Geiszt, "Dual oxidases," Philosophical Transactions of the Royal Society B: Biological Sciences, vol. 360, no. 1464, pp. 2301-2308, 2005. 
[20] G. Ferretti and T. Bacchetti, "Peroxidation of lipoproteins in multiple sclerosis," Journal of the Neurological Sciences, vol. 311, no. 1-2, pp. 92-97, 2011.

[21] A. Agarwal, A. Banerjee, and U. C. Banerjee, "Xanthine oxidoreductase: a journey from purine metabolism to cardiovascular excitation-contraction coupling," Critical Reviews in Biotechnology, vol. 31, no. 3, pp. 264-280, 2011.

[22] K.-F. Rex Sheu and J. P. Blass, "The alpha-ketoglutarate dehydrogenase complex," Annals of the New York Academy of Sciences, vol. 893, pp. 61-78, 1999.

[23] J. Fang, T. Sawa, T. Akaike, and H. Maeda, “Tumor-targeted delivery of polyethylene glycol-conjugated D-amino acid oxidase for antitumor therapy via enzymatic generation of hydrogen peroxide," Cancer Research, vol. 62, no. 11, pp. 3138-3143, 2002.

[24] A. Ambrus, B. Torocsik, L. Tretter, O. Ozohanics, and V. Adam-Vizi, "Stimulation of reactive oxygen species generation by disease-causing mutations of lipoamide dehydrogenase," Human Molecular Genetics, vol. 20, no. 15, pp. 2984-2995, 2011.

[25] M. Lechner, P. Lirk, and J. Rieder, "Inducible nitric oxide synthase (iNOS) in tumor biology: the two sides of the same coin," Seminars in Cancer Biology, vol. 15, no. 4, pp. 277-289, 2005.

[26] R. L. Levine and E. R. Stadtman, "Oxidative modification of proteins during aging," Experimental Gerontology, vol. 36, no. 9, pp. 1495-1502, 2001.

[27] E. Niki, "Lipid peroxidation: physiological levels and dual biological effects," Free Radical Biology and Medicine, vol. 47, no. 5, pp. 469-484, 2009.

[28] H. Esterbauer, R. J. Schaur, and H. Zollner, "Chemistry and biochemistry of 4-hydroxynonenal, malonaldehyde and related aldehydes," Free Radical Biology and Medicine, vol. 11, no. 1, pp. 81-128, 1991.

[29] T. Senghore, Y. F. Li, F. C. Sung et al., "Biomarkers of oxidative stress associated with the risk of potentially malignant oral disorders," Anticancer Research, vol. 38, no. 9, pp. 52115216, 2018.

[30] K. Shimada, T. Fujii, S. Anai, K. Fujimoto, and N. Konishi, "ROS generation via NOX4 and its utility in the cytological diagnosis of urothelial carcinoma of the urinary bladder," BMC Urology, vol. 11, no. 1, p. 22, 2011.

[31] E. O. Sandes, C. Lodillinsky, Y. Langle et al., "Inducible nitric oxide synthase and PPAR $\gamma$ are involved in bladder cancer progression," Journal of Urology, vol. 188, no. 3, pp. 967973, 2012.

[32] S. Kiliç, N. Bayraktar, A. Beytur, H. Ergin, M. Bayraktar, and M. Egri, "Can the levels of nitric oxide in the urine, serum and tumor tissue be putative markers for bladder cancer?," International Journal of Urology, vol. 13, no. 8, pp. 10791085, 2006.

[33] I. Gecit, M. Aslan, M. Gunes et al., "Serum prolidase activity, oxidative stress, and nitric oxide levels in patients with bladder cancer," Journal of Cancer Research and Clinical Oncology, vol. 138, no. 5, pp. 739-743, 2012.

[34] A. M. Eijan, L. E. Davel, H. A. Rueda, G. Rozenberg, E. S. De Lustig, and M. A. Jasnis, "Differential nitric oxide release and sensitivity to injury in different murine mammary tumor cell lines," International Journal of Molecular Medicine, vol. 2, no. 5, pp. 625-630, 1998.

[35] S. H. Jeon, J.-H. Park, and S.-G. Chang, "Expression of antioxidant enzymes (catalase, superoxide dismutase, and glutathione peroxidase) in human bladder cancer," Korean Journal of Urology, vol. 48, no. 9, pp. 921-926, 2007.

[36] N. Bayraktar, S. Kilic, M. R. Bayraktar, and N. Aksoy, "Lipid peroxidation and antioxidant enzyme activities in cancerous bladder tissue and their relation with bacterial infection: a controlled clinical study," Journal of Clinical Laboratory Analysis, vol. 24, no. 1, pp. 25-30, 2010.

[37] I. Gecit, R. Eryilmaz, S. Kavak et al., "The prolidase activity, oxidative stress, and nitric oxide levels of bladder tissues with or without tumor in patients with bladder cancer," The Journal of Membrane Biology, vol. 250, no. 5, pp. 455-459, 2017.

[38] I. Durak, H. Perk, M. Kavutçu, O. Canbolat, Ö. Akyol, and Y.§. Bedük, “Adenosine deaminase, 5 'nucleotidase, xanthine oxidase, superoxide dismutase, and catalase activities in cancerous and noncancerous human bladder tissues," Free Radical Biology and Medicine, vol. 16, no. 6, pp. 825-831, 1994.

[39] S. Rouf Moustafa, "Association of superoxide dismutase, glutathione peroxidase, catalse, and xanthine oxidase with incidence of bladder cancer," Cancer Research Journal, vol. 3, no. 2, pp. 17-27, 2015.

[40] N. Badjatia, A. Satyam, P. Singh, A. Seth, and A. Sharma, "Altered antioxidant status and lipid peroxidation in Indian patients with urothelial bladder carcinoma," Urologic Oncology: Seminars and Original Investigations, vol. 28, no. 4, pp. 360-367, 2010.

[41] C. R. Corso and A. Acco, "Glutathione system in animal model of solid tumors: from regulation to therapeutic target," Critical Reviews in Oncology/Hematology, vol. 128, pp. 43-57, 2018.

[42] C.-R. Yang, Y.-C. Ou, J.-H. Kuo et al., "Intracellular glutathione content of urothelial cancer in correlation to chemotherapy response," Cancer Letters, vol. 119, no. 2, pp. 157-162, 1997.

[43] O. Yalçin, F. Karataş, F. A. Erulaş, and E. Özdemir, “The levels of glutathione peroxidase, vitamin A, E, C and lipid peroxidation in patients with transitional cell carcinoma of the bladder," BJU International, vol. 93, no. 6, pp. 863-866, 2004.

[44] I. Witte, S. Altenhofer, P. Wilgenbus et al., "Beyond reduction of atherosclerosis: PON2 provides apoptosis resistance and stabilizes tumor cells," Cell Death \& Disease, vol. 2, no. 1, article e112, 2011.

[45] I. Witte, U. Foerstermann, A. Devarajan, S. T. Reddy, and S. Horke, "Protectors or traitors: the roles of PON2 and PON3 in atherosclerosis and cancer," Journal of Lipids, vol. 2012, Article ID 342806, 12 pages, 2012.

[46] T. Bacchetti, G. Ferretti, and A. Sahebkar, "The role of paraoxonase in cancer," Seminars in Cancer Biology, 2017.

[47] M. M. Utanğaç, E. Yeni, M. Savaş et al., "Paraoxonase and arylesterase activity in bladder cancer," Türk Üroloji Dergisi/Turkish Journal of Urology, vol. 43, no. 2, pp. 147-151, 2017.

[48] S. Iftimie, A. García-Heredia, F. Pujol-Bosch et al., "Serum paraoxonase-1 concentration as a potential predictor of urinary bladder cancer recurrence. A five year follow-up study," Archives of Medical Research, vol. 49, no. 2, pp. 119-122, 2018.

[49] C. Kabaroglu, I. Mutaf, B. Boydak et al., "Association between serum paraoxonase activity and oxidative stress in acute coronary syndromes," Acta Cardiologica, vol. 59, no. 6, pp. 606-611, 2004.

[50] O. Öztürk, Ö. F. Kağnici, T. Öztürk et al., “192R allele of paraoxanase 1 (PON1) gene as a new marker for susceptibility to 
bladder cancer," Anticancer Research, vol. 29, no. 10, pp. 40414046, 2009.

[51] T. Bacchetti, D. Sartini, V. Pozzi, T. Cacciamani, G. Ferretti, and M. Emanuelli, "Exploring the role of paraoxonase-2 in bladder cancer: analyses performed on tissue samples, urines and cell culturess," Oncotarget, vol. 8, no. 17, pp. 2878528795, 2017.

[52] P. Whongsiri, C. Pimratana, U. Wijitsettakul et al., "LINE-1 ORF1 protein is up-regulated by reactive oxygen species and associated with bladder urothelial carcinoma progression," Cancer Genomics \& Proteomics, vol. 15, no. 2, pp. 143-151, 2018.

[53] K. Uchida, M. Kanematsu, Y. Morimitsu, T. Osawa, N. Noguchi, and E. Niki, "Acrolein is a product of lipid peroxidation reaction: Formation of free acrolein and its conjugate with lysine residues in oxidized low density lipoproteins," Journal of Biological Chemistry, vol. 273, no. 26, pp. 1605816066, 1998.

[54] H. W. Lee, H. T. Wang, M. W. Weng et al., "Acrolein-and 4-aminobiphenyl-DNA adducts in human bladder mucosa and tumor tissue and their mutagenicity in human urothelial cells," Oncotarget, vol. 5, no. 11, pp. 3526-3540, 2014.

[55] İ. A. Yılma, T. Akçay, U. Çakatay, A. Telci, S. Ataus, and V. Yalçın, "Relation between bladder cancer and protein oxidation," International Urology and Nephrology, vol. 35, no. 3, pp. 345-350, 2003.

[56] T. B. Kryston, A. B. Georgiev, P. Pissis, and A. G. Georgakilas, "Role of oxidative stress and DNA damage in human carcinogenesis," Mutation Research/Fundamental and Molecular Mechanisms of Mutagenesis, vol. 711, no. 1-2, pp. 193201, 2011.

[57] C. Cao, T. Lai, M. Li et al., "Smoking-promoted oxidative DNA damage response is highly correlated to lung carcinogenesis," Oncotarget, vol. 7, no. 14, pp. 18919-18926, 2016.

[58] T. Wada, N. Tanji, A. Ozawa et al., "Mitochondrial DNA mutations and 8-hydroxy-2'-deoxyguanosine content in Japanese patients with urinary bladder and renal cancers," Anticancer Research, vol. 26, no. 5A, pp. 3403-3408, 2006.

[59] A. Cormio, F. Sanguedolce, C. Musicco et al., "Mitochondrial dysfunctions in bladder cancer: exploring their role as disease markers and potential therapeutic targets," Critical Reviews in Oncology/Hematology, vol. 117, pp. 67-72, 2017.

[60] K. M. Patel, K. E. van der Vos, C. G. Smith et al., "Association of plasma and urinary mutant DNA with clinical outcomes in muscle invasive bladder cancer," Scientific Reports, vol. 7, no. 1, article 5554, 2017. 


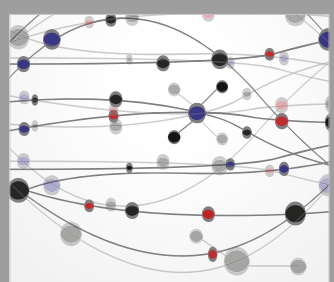

The Scientific World Journal
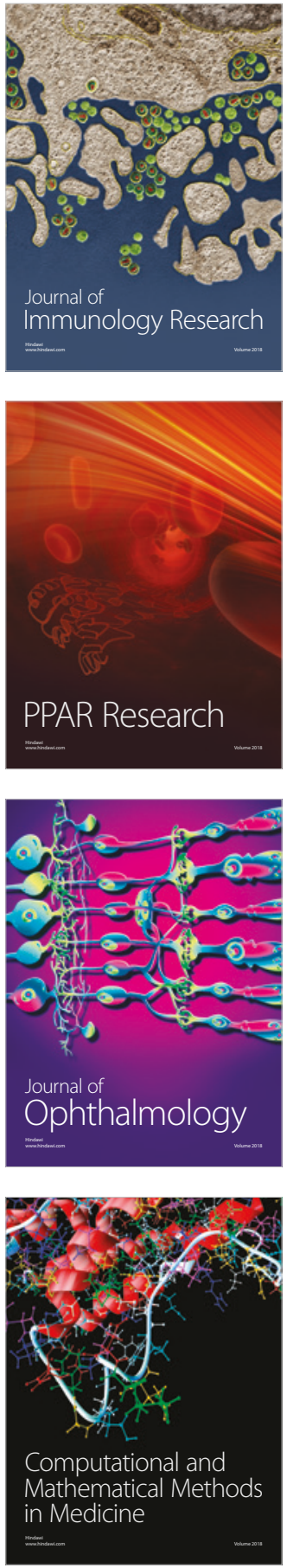

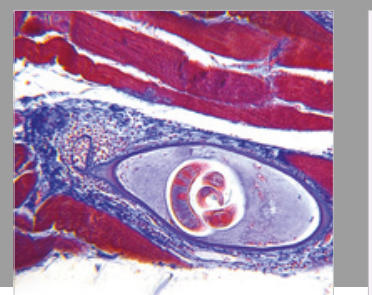

Gastroenterology Research and Practice

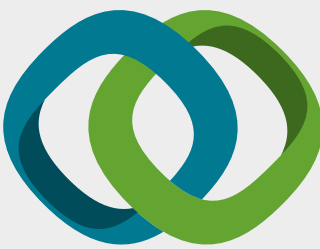

\section{Hindawi}

Submit your manuscripts at

www.hindawi.com
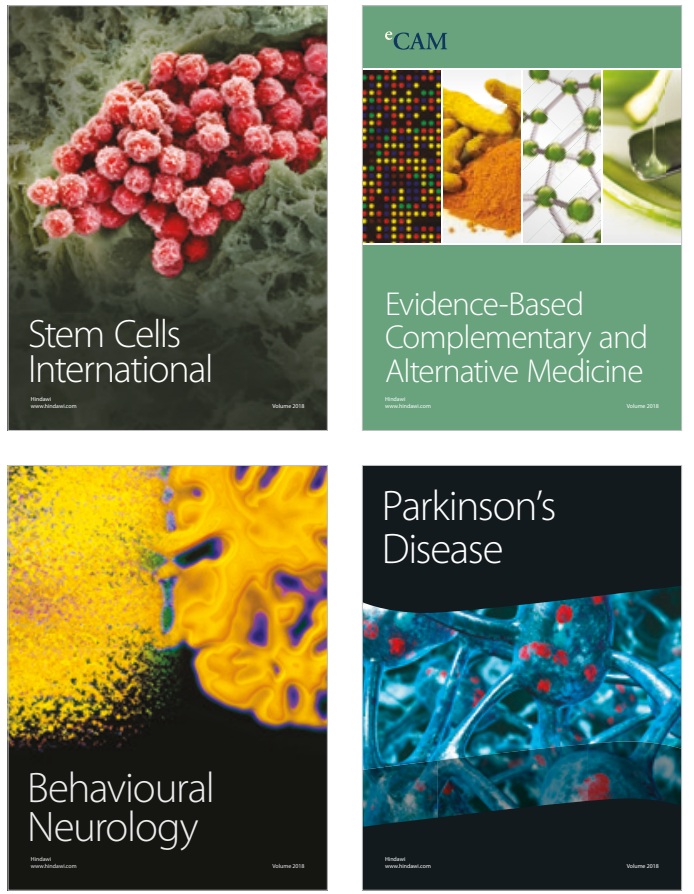

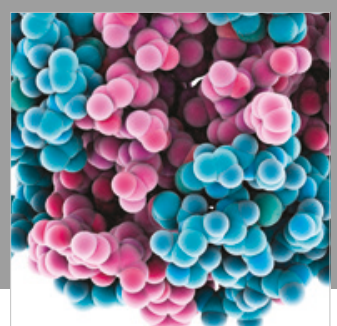

ournal of

Diabetes Research

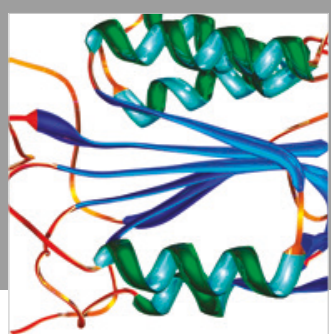

Disease Markers
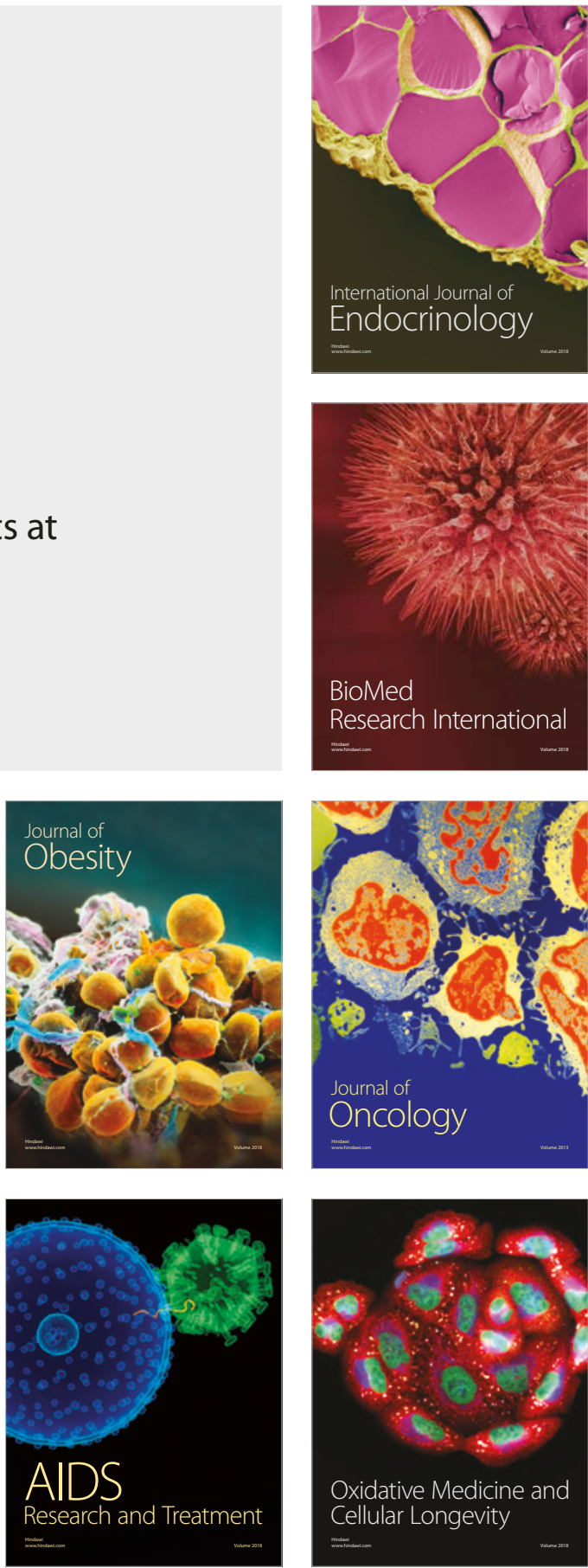